\title{
The Impact of Bailout on Financial Performance And Bank Risk-Taking During Financial Crisis: A Critical Systematic Review
}

\author{
Dety Nurfadilah ${ }^{1 *}$ \\ ${ }^{1}$ Faculty of Economics, Universitas Krisnadwipayana, Jakarta 13077, Indonesia
}

\begin{abstract}
A B S T R A C T
The focus on the bank bailout has been increased since the global financial crisis in 2008 in most countries. However, previous studies often discover the relationship between bailout and corporate governance. In this study, bank bailout literature will be reviewed with the focus on the impact of bailout on bank financial performance and bank risk-taking during the financial crisis. Multi-step strategy is used to collect the data from 2000 to 2016. From the 7 papers were chosen based on the criteria. This systematic review has shown that the bank bailout has a positive impact on financial performance, however, it has a negative impact on bank risk-taking for a longer period.
\end{abstract}

ART I CLE IN F O

\section{Keywords:}

Bailout,

Financial Crisis,

Systematic Review,

Bank Risk-Taking,

Financial Performance
*Corresponding Author E-mail: detynurfadilah@gmail.com

\section{INTRODUCTION}

The global financial crisis in 2007-2009 has hit the real economy of the whole world. According to Dhameja (2010), this crisis is worse than the great depression crisis in the 1930s. This crisis is spreading to the entire global financial system. Financial crisis triggers economic consequences of inflation, unemployment, drop in purchasing power and increases public doubt about its ability to provide service. The global financial crisis led to a bank collapsed in the financial sectors of several important developed countries (Barth et al., 2012).
Currently, 465 failed banks in United States closed by the Federal Deposit Insurance Corporation (FDIC) from the Initial crisis in 2008 to 2012, namely New Century, American Home Mortgage, Netbank, Bear Stearns, Fannie Mae and Freddie Mac, Merrill Lynch, Lehman Brother, Washington Mutual, American International Group, HSBC Finance Corporation, and so forth so on (Andrews et al, 2016; Karnitschnig et al, 2014; Ivashina \& Scharfstein, 2009). In Europe and Central Asia region, the financial crisis has caused the bank collapsed, namely Glitnir, Kaupthing and 
Landsbanki in Iceland; Bankia, CatalunyaCaixa, CajaSur in Spain; Parex Bank in Latvia; UBS in Switzerland; Fortis and BNP Paribas in Belgian and Luxembourg; Bank of Antigua in Eastern Caribbean; Banco Privado Portugues in Portugal; Anglo Irish Bank in Ireland; BTA bank and Alliance bank in Kazakhstan and so forth so on (White, 2008; Mclaughlin \& Levring, 2008). In the Asia Pacific region, it caused the collapse of Lehman brothers in Japan and Bank West in Australia (KyodoNews, 2008; Kramer \& Andrews, 2009). According to Terazi and Şenel (2011), an unprecedentedly large number of failed banks has increased the government attention to enacted a range of rescue plans to help banks restore its health and confidence, as well as increase its financial stability. In 2007, The US Federal Reserve offered a loan to several banks and made more funding available around $\$ 20 \mathrm{bn}$, then European Central Bank offered $\$ 500 \mathrm{bn}$ to assist commercial banks. In 2008, United States launched Troubled Asset Relief Program (TARP) with the total fund given around \$700bn (Guillén, 2009), while British Government launched a bank rescue package with approximately $\$ 850$ billion. According to the International Monetary Fund (2010), Latvia in the Baltic States suffered from the crisis and urged to ask for financial support. The government support continues until this day. In 2016, Italy government approve to give fund around $€ 20 \mathrm{bn}$ to support Monte Dei Paschi di Siena (BBC, 2016).

However, previous researchers argue that bailout is making the bank worse in many ways. It increases the bank risk-taking, volatility, and default risk, and create a moral hazard problem (Duchin and Sosyura, 2014). Unfortunately, this issue is often ignored by the government and other financial aid bodies because they are focusing on "too big to fail institution" mindset. Also, the cost of the bailout is very expensive. Every decision made by the government will have consequences on bank performance. Gerhardt and Vennet (2016) added that the massive bailout program has increased the question about the effect on government intervention on future bank behavior. Therefore, there is an increasing need to understand the impact of government financial aid on bank crisis performance and its risk-taking.

To the best of author's knowledge, this is the first study to create a comprehensive systematic review on this issue. To date, the existing studies have examined the effect of bailout on bank future behavior (Fisher et al., 2012; Dam and Koetter, 2012; Gropp et al., 2011), impact of capital injections (Duchin and Sosyura, 2013; Berger et al. (2011); Mehran and Thakor (2011). A critical review of the literature was conducted to address the following question: what is the impact of bailout on bank performance during the financial crisis? And what is the impact of bailout on bank risk-taking during the financial crisis?

This study is organized as follows: section 1 present the background of the study, section 2 describe research methodology, section 3 state the result, section 4 discuss the result, section 5 describes the limitations, and section 6 concludes the study.

\section{RESEARCH METHOD \\ Design}

Systematic review and narrative are used in this study to present a critical overview of the research topic and evaluate the quality of the previous studies (Ressing etal., 2009). A systematic review is one type of literature review that collect and summarize all studies based on criteria (Khan et al., 2003). This systematic reviews aimed to systematically examine the scientific literature to understand the impact of bailout on bank performance and bank risk-taking.

\section{Search Strategy}

To achieve the research objectives, multiple-step search strategy was adopted from the previous study in the field of financial institution (International Finance Corporation, 2013), nurse services (Carter and Chochinov, 2007; Jennings et al., 2015), and construction management (Hong et al, 2012; Yi and Wang, 2013; Osei-Kyei and Chan, 2015). The two-step review was used to get a high-quality paper. At the first stage, the authors created a list of thematic field group about the bailout. At the second stage, this list was narrowed down to sub-theme focusing on the impact on bank 
performance and bank risk-taking (fig.1).

A comprehensive search was carried out under the "abstract / title / keywords". The search keywords include "bailout financial crisis", "government support financial crisis", "bailout corporate governance", "bank bailout", "bank performance in financial crisis", "bailout bank risk", "bank risk-taking bailout". In addition, the search was restricted to the field of study "accounting and finance", "business, management, and accounting", "economics, econometrics, and finance", "social science". The third step, keywords were combined using AND and OR. The full search code is listed as follows:

ABS-TITLE-KEY ("bailout" OR "financial crisis" OR "bank performance" OR government support" OR "bank bailout" OR impact bailout) AND ABS-TITLEKEY (bank crisis performance" OR "bank risktaking" OR "effect bailout") AND SUBJAREA (busi OR manag OR Acc OR econ OR soci) AND PUBYEAR N 2000 AND PUBYEAR b 2017 AND LANGUAGE ("English”) AND SRCTYPE (j).

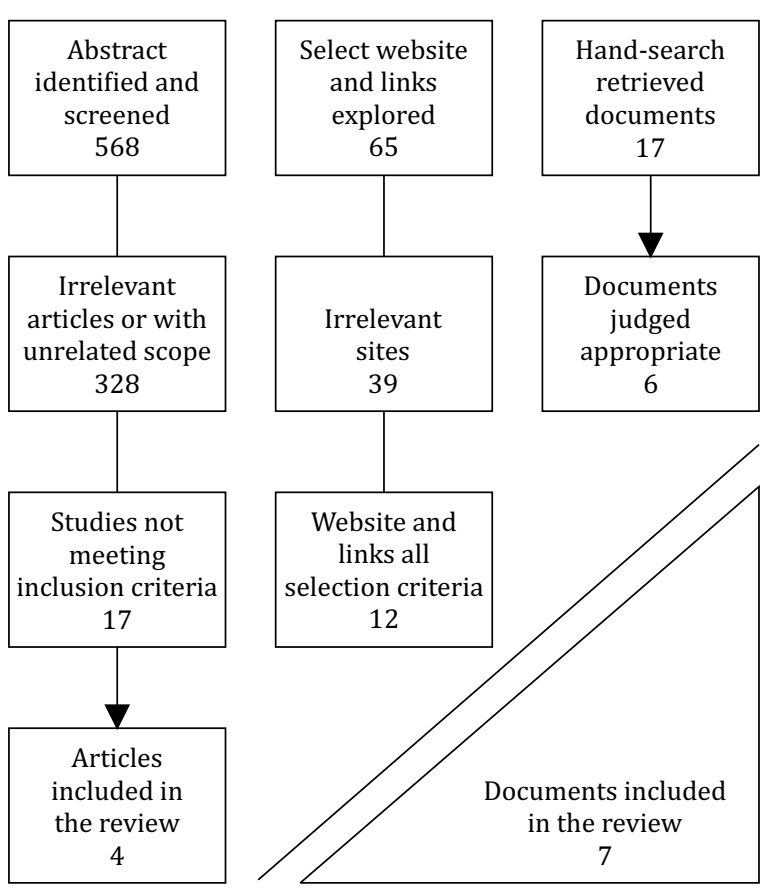

Figure 1. Flow of Research
In this study, a range of academic research database is used to collect the data such as SSRN website, Emerald Insight, Science Direct, Proquest, Springerlink, business EBSCOHOST, and google scholar. Science Direct and Emerald Insight have been considered as a database that performed better than another database website (Falagas et al, 2008; Ke et al., 2009; Yuan and Shen, 2011; Osei-Kyei and Chan, 2015).

\section{Inclusion and Exclusion Criteria}

According to Meline (2006), the process of systematic review consists of predetermined criteria which are included and excluded from the research. Chambers (2004) added that studies are excluded from the collection of literature if they meet the following criteria: (1) definitely meet one or more of exclusion criteria, (2) contain ambiguous methods, (3) does not contain sufficient data or statistics, or (4) does not meet the predetermined criteria for quality. To achieve the goal of this research, several inclusion and exclusion criteria are as follows:

Table 1. Inclusion and Exclusion Criteria

Inclusion Criteria:

(I) Published articles relevant to the impact of bank bailout on bank-risk taking and financial performance during financial crisis.

(ii) Articles published from 2006 to 2017.

(iii) The article types are journals, books, literature review, conceptual study, empirical study.

(iv) Articles are written in English.

(v) Exploring impact of bailout on bank performance and bank risk-taking.

(vi) All countries which suffered from financial crisis.

(vii) Literature focusing on any types of bailout: government, financial authority, IMF, and etc.

Inclusion Criteria:

(I) Papers in non-English language and without English translation.

(ii) Magazine, newspaper, or blog which are not based on theoretical or empirical study.

(iii) Literature focusing on non-default bank. 


\section{RESULT}

\section{Overview of Search Results}

Table 2. Included study objectives and measurements

\begin{tabular}{|c|c|c|c|c|c|}
\hline Author \& Year & Aims & $\begin{array}{l}\text { Data Collection } \\
\text { Methods }\end{array}$ & Participants & $\begin{array}{l}\text { Key focus/ } \\
\text { statement of } \\
\text { problem }\end{array}$ & Outcome \\
\hline $\begin{array}{l}\text { Gerhardt and } \\
\text { Vennet (2016) }\end{array}$ & $\begin{array}{l}\text { Investigate the } \\
\text { financial condition } \\
\text { of banks before } \\
\text { and after receiving } \\
\text { state Bank bailout, } \\
\text { financial crisis }\end{array}$ & $\begin{array}{l}\text { Multivariate logit } \\
\text { regression }\end{array}$ & $\begin{array}{l}114 \text { Banks in } \\
\text { European regions }\end{array}$ & $\begin{array}{l}\text { Limited literature } \\
\text { for government } \\
\text { support during } \\
\text { financial crisis }\end{array}$ & $\begin{array}{l}\text { Equity ratio, loan } \\
\text { loss provision, } \\
\text { nonperforming } \\
\text { loans and bank } \\
\text { size perform well } \\
\text { in detecting bank } \\
\text { bailout }\end{array}$ \\
\hline $\begin{array}{l}\text { Black and } \\
\text { Hazelwood } \\
(2012)\end{array}$ & $\begin{array}{l}\text { Investigate the } \\
\text { effect of the TARP } \\
\text { or government } \\
\text { program on bank } \\
\text { risk taking by } \\
\text { analyzing } \\
\text { the risk ratings of } \\
\text { banks' commercial } \\
\text { loan during crisis }\end{array}$ & $\begin{array}{l}\text { Survey of Terms } \\
\text { of Business } \\
\text { Lending (STBL) } \\
\text { from November } \\
2007 \text { to August } \\
2010\end{array}$ & $\begin{array}{l}81 \text { banks } \\
\text { (including } 37 \\
\text { TARP banks and } \\
44 \text { non-TARP } \\
\text { banks) }\end{array}$ & $\begin{array}{l}\text { Government aid } \\
\text { induce excessive } \\
\text { risk-taking }\end{array}$ & $\begin{array}{l}\text { The risk of loan } \\
\text { originations } \\
\text { increased at large } \\
\text { TARP banks but } \\
\text { decreased at small } \\
\text { TARP banks. } \\
\text { Interest spreads } \\
\text { and loan levels also } \\
\text { moved in different } \\
\text { directions for large } \\
\text { and small banks }\end{array}$ \\
\hline $\begin{array}{l}\text { Gine and Martin } \\
\text { (2014) }\end{array}$ & $\begin{array}{l}\text { Explore the credit } \\
\text { market } \\
\text { implications and } \\
\text { real effects of one } \\
\text { the largest } \\
\text { borrower bailout } \\
\text { programs in } \\
\text { history }\end{array}$ & $\begin{array}{l}\text { Dataset is a panel } \\
\text { covering } 489 \\
\text { (of } 593 \text { total) } \\
\text { districts of India } \\
\text { from } 2001 \text { to } 2012\end{array}$ & $\begin{array}{l}\text { Government of } \\
\text { India }\end{array}$ & $\begin{array}{l}\text { Important } \\
\text { changes in bank } \\
\text { lending and credit } \\
\text { allocation }\end{array}$ & $\begin{array}{l}\text { The stimulus } \\
\text { program had no } \\
\text { effect on } \\
\text { productivity, } \\
\text { wages, or } \\
\text { consumption, but } \\
\text { led to significant } \\
\text { changes in credit } \\
\text { allocation and an } \\
\text { increase in defaults. } \\
\text { Post-program loan } \\
\text { performance } \\
\text { declines faster in } \\
\text { districts with } \\
\text { greater exposure to } \\
\text { the program, an } \\
\text { effect that is not } \\
\text { driven by greater } \\
\text { risk-taking of } \\
\text { banks. Loan } \\
\text { defaults become } \\
\text { more significantly } \\
\text { more sensitive to } \\
\text { the electrical cycle } \\
\text { after the program }\end{array}$ \\
\hline $\begin{array}{l}\text { Fernandes, } \\
\text { Farinha, Martins, } \\
\text { and Mateus } \\
(2016)\end{array}$ & $\begin{array}{l}\text { Investigate the } \\
\text { determinants of } \\
\text { bank's bailout in } \\
\text { European banks } \\
\text { during crisis }\end{array}$ & $\begin{array}{l}\text { Using probit model } \\
\text { that analyse board } \\
\text { characteristics } \\
\text { variables (board } \\
\text { independence, size, } \\
\text { CEO duality, board } \\
\text { experience, director } \\
\text { tenure, board } \\
\text { busyness), risk } \\
\text { variables (credit, } \\
\text { liquidity, and growth } \\
\text { risk), banks variable } \\
\text { (size and capital), } \\
\text { control variable } \\
\text { (bank-level, country } \\
\text { banking sector, and } \\
\text { macroeconomic, } \\
\text { regulatory, corruption) }\end{array}$ & $\begin{array}{l}\text { Europe, Banks } \\
\text { which have } \\
\text { received bailout } \\
\text { funds }\end{array}$ & $\begin{array}{l}\text { The enormous } \\
\text { volume of financial } \\
\text { crisis and bailout } \\
\text { has increased the } \\
\text { need to } \\
\text { understand the } \\
\text { determinants of } \\
\text { bailout and there } \\
\text { is no previous } \\
\text { research which } \\
\text { investigate the } \\
\text { determinants of } \\
\text { probability of } \\
\text { bailouts during } \\
\text { financial crisis }\end{array}$ & $\begin{array}{l}\text { The governance } \\
\text { characteristics of } \\
\text { banks, specifically } \\
\text { the characteristics } \\
\text { of boards, bank } \\
\text { risks, as well as } \\
\text { bank-level and } \\
\text { country-specific } \\
\text { banking sector } \\
\text { features, explain } \\
\text { the likelihood of } \\
\text { bailouts in the } \\
\text { European banking } \\
\text { sector }\end{array}$ \\
\hline
\end{tabular}




\begin{tabular}{|c|c|c|c|c|c|}
\hline $\begin{array}{l}\text { Berger, Roman, } \\
\text { and Sedunov } \\
(2016)\end{array}$ & $\begin{array}{l}\text { Bailouts, systematic } \\
\text { risk, financial crisis, } \\
\text { U.S Troubled Assets } \\
\text { Relief Program } \\
\text { (TARP) }\end{array}$ & $\begin{array}{l}\text { Difference in } \\
\text { difference method } \\
\text { for the period } \\
\text { October } 2008 \text { to } \\
\text { December } 2010 \text {. } \\
\text { Main dependent } \\
\text { variables consists } \\
\text { of expected capital } \\
\text { shortfall and } \\
\text { systemic expected } \\
\text { shortfall, while } \\
\text { independent } \\
\text { variable consists } \\
\text { of bank size, the } \\
\text { natural log of GTA, } \\
\text { HHI deposits, and } \\
\text { number of } \\
\text { branches }\end{array}$ & commercial banks & $\begin{array}{l}\text { countries on } \\
\text { systemic risk }\end{array}$ & $\begin{array}{l}\text { contributions to } \\
\text { systemic risk, } \\
\text { consistent with } \\
\text { a stabilization of } \\
\text { the financial } \\
\text { system. This } \\
\text { finding is robust } \\
\text { to a battery of } \\
\text { robustness checks. } \\
\text { Furthermore, our } \\
\text { study complements } \\
\text { the existing } \\
\text { empirical bailout } \\
\text { literature and adds } \\
\text { to the broad } \\
\text { debate on the } \\
\text { benefits and costs } \\
\text { of bailouts }\end{array}$ \\
\hline
\end{tabular}

Table 3. Result and interpretation of included studies impact of bailout on bank performance and bank risk taking

\begin{tabular}{|c|c|c|}
\hline Outcome measures & Results & Interpretation \\
\hline \multicolumn{3}{|l|}{ 1. Bank performance } \\
\hline Gerhardt and Venner (2016) & $\begin{array}{l}\text { The equity ratio is the decisive indicator } \\
\text { to predict stress. The aided banks hardly } \\
\text { improve their performance indicators } \\
\text { after they have been rescued but } \\
\text { maintain similar risk profiles/business } \\
\text { models }\end{array}$ & $\begin{array}{l}\text { When government set up state- } \\
\text { sponsored rescues, they should require } \\
\text { rapid and decisive action from the } \\
\text { rescued banks in terms of business } \\
\text { model redesign and structural } \\
\text { governance changes. The faster banks } \\
\text { restore their resilience, the better they } \\
\text { can again contribute to the financing of } \\
\text { the real economy. }\end{array}$ \\
\hline Gianneti and Simonov (2009) & $\begin{array}{l}\text { Government recapitalizations increase } \\
\text { the value of bank clients, especially if } \\
\text { these have high leverage and are } \\
\text { therefore very dependent on bank } \\
\text { financing. After recapitalizations, banks } \\
\text { extend larger loans to their existing } \\
\text { borrowers. }\end{array}$ & $\begin{array}{l}\text { Recapitalizations allow banks to supply } \\
\text { larger loans to deserving and } \\
\text { undeserving firms alike and that the } \\
\text { positive effects on the valuation of } \\
\text { undeserving firms are much larger, } \\
\text { especially if the amount invested to } \\
\text { recapitalize banks is insufficient to } \\
\text { re-establish high levels of bank } \\
\text { capitalization. This suggests that } \\
\text { capital injections may increase the } \\
\text { misallocation of credit if they are not } \\
\text { appropriately designed. }\end{array}$ \\
\hline \multicolumn{3}{|l|}{ 2. Bank risk taking } \\
\hline Berger, Roman, and Sedunov (2016) & $\begin{array}{l}\text { Bank bailouts can help stabilize the } \\
\text { financial system, bailouts may be most } \\
\text { effective in this regard if they are } \\
\text { targeted toward larger banks, safer } \\
\text { banks, and banks in markets with better } \\
\text { economic conditions, bailouts may be } \\
\text { most effective when the systemic } \\
\text { problems are at their worst, and one } \\
\text { particular form of bailout, injections of } \\
\text { preferred equity, appears to work } \\
\text { successfully to reduce systemic risk } \\
\text { through reduced leverage risk. These } \\
\text { findings are only based on consideration } \\
\text { of systemic risk. }\end{array}$ & $\begin{array}{l}\text { Bailout program conducted by } \\
\text { government or external bodies may } \\
\text { affect systemic risk through altering } \\
\text { individual bank leverage risk, portfolio } \\
\text { risk, or systemic importance. It is also } \\
\text { important to analyse the most and least } \\
\text { effective bailout program in reducing } \\
\text { contribution to systemic risk and help in } \\
\text { determine the future effective bailout } \\
\text { and additional policies, such as } \\
\text { restrictions on common equity dividends } \\
\text { or buybacks to restrict leverage risk, } \\
\text { tighter supervision or regulation of } \\
\text { portfolio risk or limits on executive } \\
\text { compensation to offset increased moral } \\
\text { hazard incentives, or stiffer requirements } \\
\text { for M\&A approvals to offset too-big-to- } \\
\text { fail incentives created by bailouts. }\end{array}$ \\
\hline
\end{tabular}




\begin{tabular}{|l|l|l|}
\hline Schiozer and Vilarins (2016) & $\begin{array}{l}\text { Financial institutions with high bailout } \\
\text { expectations assume higher risks than } \\
\text { others. In normal times, rescue } \\
\text { guarantees to large financial institutions } \\
\text { distort competition in the sector and } \\
\text { increase the risk of the other institutions. } \\
\text { However, during the recent financial } \\
\text { crisis, increases in the rescue expectation } \\
\text { of competitors of an institution, to the } \\
\text { extent that they represent a reduction in } \\
\text { its chance of bailout, decrease its } \\
\text { risk taking. }\end{array}$ & $\begin{array}{l}\text { The bailout expectation and the total } \\
\text { assets of an institution are associated } \\
\text { with greater risk taking. In addition, the } \\
\text { rescue expectation of the competitors of } \\
\text { an institution also influences its risk } \\
\text { taking. However, depending on the } \\
\text { period of analysis, this link can be } \\
\text { different; that is, in normal periods, there } \\
\text { is a predominance of the channel } \\
\text { through which increases in the distort } \\
\text { competition, reduce profit margins, and } \\
\text { increase the risk taking of small } \\
\text { institutions. During crises, however, } \\
\text { increases indicate lower risk taking. It is } \\
\text { assumed that the reason is, the higher of } \\
\text { an institution, the lower its relative } \\
\text { importance in the system and thus the } \\
\text { lower its prospect of eventually being } \\
\text { rescued. }\end{array}$ \\
& \\
& \\
&
\end{tabular}

\section{DISCUSSION}

\section{Implications for banking evaluation}

Bailout program has supported many struggling banks from collapse. According to Gerhardt and Vennet (2016), there were approximately 114 banks received bailout in the European region during the period 2007-2013. Bailout program has been launched by the government to avoid the bank collapse, ensure the effectiveness of payment system, and minimize the negative impact on the economy (Grande et al., 2011; Beck et al., 2010; Panetta et al., 2009). the effects of bailouts may differ across types of banks. Information on the relative effectiveness of bailouts for different types of banks is key to targeting any future bailouts. Choi (2014) stated that recapitalization of stronger rather than weaker banks could more effectively reduce systemic risk.

Berger, Roman, and Sedunov (2016) mentioned that there are few things to be considered before choosing a bailout program. First, when future financial crises occur and policymakers consider their options, it is helpful to know whether bailouts tend to combat systemic risk versus make the problem worse. Second, bailouts may affect systemic risk through many different channels. Some of them operate through altering individual bank capital and leverage risk, others influence individual bank portfolio risk, and a third set involves increasing bank systemic importance.
Knowledge of which channels are most effective may be valuable in the design of future bailouts and accompanying policies. Third, there are a variety of bailout methods, including injections of preferred equity, blanket guarantees, extending liquidity support, nationalizations, and many others. Information on whether specific types of bailouts reduce or increase systemic risk may provide insights for designing any future bailouts that might be considered.

\section{Limitations}

This study has some limitations where it only focusses on bank performance and bank-risk taking, while other indicators can be used for the future suggestion, namely bank efficiency, bank distress, interventions, moral hazard.

\section{CONCLUSION}

The finding from this systematic literature review suggest the emergency government financial aid do impact bank performance positively. However, the impact of bank risk taking for the future needs to be evaluated by robust research to produce evidence that informs corporate governance development. This will in turn to provide context for further studies and provide an evidence base for government and bank practitioners to ensure the sustainability and ongoing bailout and corporate governance reform model. 


\section{RE F EREN CES}

Behr, P., Wang, W. (2018). The (un) desired effects of government bailouts: The impact of TARP on the interbank market and bank risk-taking. Available at SSRN: https://ssrn.com/abstract=3192503

Carter, A.J.E., Chochinov, A.H. (2007). A systematic review of the impact of nurse practitioners on cost, quality of care, satisfaction and wait times in the emergency department. CJEM, 9, 286-295.

Dhameja, N. (2010). Financial Crisis: Impact, Challenges and Way Out. Indian Journal of Industrial Relations, 45(3): 11-16.

Duchin, R., Sosyura, D. (2014). Safer ratios, riskier portfolios: bank's response to government aid. Journal of Financial Economics, 113,1-28.

Guillén, M. F. (2009). The global economic \& financial crisis: a timeline. The lauder Institute.

International Finance Corporation. (2013). Systematic review of SME banking and business regulation.

Ivashina, V., Scharfstein, D. (2009). Bank lending during the financial crisis of 2008. Journal of Financial Economics, 97(3), 319-338.

Jennings, N., Clifford, S., Fox, A. R., O'Connel, J., Gardner, G. (2015). The impact of nurse practitioner services on cost, quality of care, satisfaction and waiting times in the emergency department: A systematic review. International Journal of Nursing Studies, 52, 421-435.

Khan, K. S., Kunz, R., Kleijnen, J., Antes, G. (2003). Five steps to conducting systematic review. Journal of the Royal Society of Medicine, 96(3), 118-121.

Lu, W., Whidbee, D. A. (2016). US bank failure and bailout during the financial crisis: examining the determinants of regulatory intervention decisions. Journal of Financial Economic Policy, 8(3), 316347.

Meline, T. (2006). Selecting studies for systematic review: Inclusion and exclusion criteria. Contemporary Issues in Communication Science and Disorders, 33, 21-27.

Pae, C. (2015). Why systematic review rather than narrative review?. Psychiatry Investigation, 12(3), 417-419. 